\title{
Effects of Anterior Pituitary Isograft in the Neonatal Female Mouse in the Pattern of Estrous Cycle and the Structure of Mammary Glands
}

\author{
TAKAO MORI \\ Zoological Institute, Faculty of Science, \\ University of Tokyo, Tokyo 133
}

\begin{abstract}
Synopsis
Neonatal female mice were given subcutaneous implants of the anterior pituitary from young male donors of the same inbred colony. Similar mice given an isograft of a piece of the submaxillary gland served as controls. When examined at the age of 1,3 or 5 months, the isografted tissues were not recovered from any of these animals. Correlation analyses of estrous cycles were carried out. Studies of the autocorrelation function revealed that, in a majority of mice receiving pituitary isografts, their estrous cycles were irregular, characterized by prolonged vaginal estrus and/or prolonged diestrus continuing for periods of different length. The mean weight of the pituitary in situ was significantly smaller in these animals than that in the control mice. A similar fall of pituitary weights also occurred in mice ovariectomized on the day of pituitary implantation. This fact suggests that the pituitary isograft directly inhibits the growth of the pituitary in situ but not indirectly, via the ovaries. At 5 months of age, the ovaries of mice given pituitary grafts were enlarged, having so many corpora lutea, as compared with those of the control animals. This finding suggests that the neonatal pituitary implantation resulted in an increased secretion of gonadotropins from the pituitary in situ. In mice which had been given pituitary implants and showed prolonged, though not persistent, vaginal diestrus, the mammary glands contained well-developed branching ducts with a number of isolated alveoli. The pituitaries in situ appeared to have been permanently affected by neonatal pituitary isografts.
\end{abstract}

According to the preliminary experiment (Mori and Bern, 1972b), anterior pituitary isografts in female mice on the day of birth produce mice which show irregular estrous cycles characterized by a prolonged estrous and/or a prolonged diestrous, a retardation in the growth of the pituitary in situ and a development of the mammary glands. In female rats, similar neonatal pituitary isoimplantations result in a decrease in weight of the host's own pituitaries and an increase in weight of the ovaries (Mori and Matsumoto, 1974).

The present paper deals with changes in the

Received for publication February 16, 1974. function of the anterior pituitaries of female mice given pituitary isografts on neonatal days and discusses the causation of functional alterations in the pituitaries in situ.

\section{Materials and Methods}

An anterior pituitary was isografted together with a piece of black cellophane as a marker under the back skin of female $\mathrm{C} 3 \mathrm{H} / \mathrm{Tw}$ and $\mathrm{ddY}$ mice on the day of birth or at 6 days of age. The donors were 2-month-old male mice belonging to the same inbred colony. Control mice received similar implants of a piece of the submaxillary gland. Some mice were ovariectomized on the day of birth prior to implantation. Sacrifices were performed at $35,80-90$ or $140-150$ days of age. The experimental schedules are sum- 
marized in Table 1.

Vaginal smears were examined daily at 9 A.M. from the day of vaginal opening until sacrifice. The correlation analysis ( $c f$. Blackman and Tukey, 1958; Isobe, 1968) of data of the estrous cycle was carried out by assuming numerical values of diestrous, proestrous and estrous as 1,2 and 3, respectively. The autocorrelation functions of the estrous curve for two periods of 30 days each, starting from 40 and 100 days of age, were determined. The autocorrelation function of a waveform $X(t)$ at lag $(q \Delta \tau)$ is approximated the equation

$$
C(q \Delta \tau)=\sum_{q=0}^{15} X(t) X(t+q \Delta \tau)
$$

where $\Delta \tau$ is the delay increment ( 1 day) and the total delay span is 15 days. The normalized ratios $C(q \Delta \tau) /$ $C(0)$ were plotted against the time axis, where $C(0)$ is the autocorrelation function with zero time shift.

Ovaries and adrenals were fixed in Bouin's fluid after being weighed. Sections cut at $7 \mu$ were stained with Delafield's haematoxylin, alcian-blue and eosin.
Mammary glands were fixed in Tellyesniczky's fluid, and haematoxylin stained whole-mounts were prepared. At autopsy, the isografted tissues were not found in any of the animals. Significance of differences between data of pituitary-implanted and control animals was determined by the Student $t$ test.

\section{Results}

Vaginal opening and the first estrous occurred at the age of 29-30 and 31-32 days respectively in both $\mathrm{C} 3 \mathrm{H}$ mice given pituitary isografts (Group 1) and those receiving submaxillary grafts (Group 2). In ddY mice, both vaginal opening and the first estrous took place in the mice given pituitary grafts (Group 3) earlier than in the controls (Group 4) (Table 2).

Table 1. Experimental schedules

\begin{tabular}{|c|c|c|c|c|c|c|}
\hline $\begin{array}{l}\text { Strain } \\
\text { of mice }\end{array}$ & Group & $\begin{array}{l}\text { No. of } \\
\text { mice }\end{array}$ & $\begin{array}{l}\text { Pituitary } \\
\text { isograft* }\end{array}$ & $\begin{array}{l}\text { Ovari- } \\
\text { ectomy }\end{array}$ & $\begin{array}{l}\text { Age in days } \\
\text { at implanta- } \\
\text { tion }\end{array}$ & $\begin{array}{l}\text { Age in days } \\
\text { at autopsy }\end{array}$ \\
\hline \multirow[t]{5}{*}{$\mathrm{C} 3 \mathrm{H}$} & 1 & 21 & + & - & 0 & $140-150$ \\
\hline & 2 & 14 & - & - & 0 & $140-150$ \\
\hline & 3 & 12 & + & - & 0 & $80-90$ \\
\hline & 4 & 13 & - & - & 0 & $80-90$ \\
\hline & 5 & 14 & + & - & 6 & $80-90$ \\
\hline \multirow[t]{4}{*}{ ddY } & 6 & 7 & + & - & 0 & 35 \\
\hline & 7 & 7 & - & - & 0 & 35 \\
\hline & 8 & 10 & + & + & 0 & $80-90$ \\
\hline & 9 & 10 & - & + & 0 & $80-90$ \\
\hline
\end{tabular}

Notes: * Minus (-) indicates the control mice given submaxillary isografts.

Table 2. Ages in days at vaginal opening and first estrous, and numbers of mice showing prolonged estrous and/or prolonged diestrous

\begin{tabular}{|c|c|c|c|c|c|}
\hline Group & $\begin{array}{l}\text { Vaginal } \\
\text { opening } \\
\text { (days) }\end{array}$ & $\begin{array}{l}\text { First } \\
\text { estrous } \\
\text { (days) }\end{array}$ & $\begin{array}{l}\text { Prolonged } \\
\text { estrous, over } \\
5 \text { days' } \\
\text { duration } \\
\text { (No. of mice) }\end{array}$ & $\begin{array}{l}\text { Prolonged } \\
\text { diestrous } \\
\text { over } 5 \text { days' } \\
\text { duration } \\
\text { (No. of mice) }\end{array}$ & $\begin{array}{l}\text { Regular } \\
\text { estrous } \\
\text { cycle } \\
\text { (No. of } \\
\text { mice) }\end{array}$ \\
\hline 1 & $28.9 \pm 0.9^{*}$ & $32.3 \pm 1.0$ & 9 & 21 & 0 \\
\hline 2 & $29.7 \pm 0.6$ & $31.4 \pm 0.2$ & 2 & 2 & 11 \\
\hline 3 & $29.6 \pm 0.9^{a}$ & $33.1 \pm 1.3^{b}$ & 4 & 10 & 2 \\
\hline 4 & $34.5 \pm 1.4^{a}$ & $44.6 \pm 3.1^{b}$ & 0 & 1 & 12 \\
\hline
\end{tabular}

Notes: * Mean \pm S.E.

Each difference between a couple of means marked with the same small letter is significant at a $5 \%$ level of confidence with the $t$-test. 
Almost all mice receiving pituitary isografts showed prolonged vaginal estrous lasting 5-11 days and/or prolonged diestrous lasting 5-28 days. Table 2 shows some instances of irregular cycles. Vaginal smears of ovariectomized mice receiving pituitary isografts showed no estrous phase (Group 8). In control mice, the autocorrelation function of the estrous cycles indicated regular 4-day rhythmicity during 2 periods of 30 days, i.e. $40-70$ days of age and 100-130 days of age (Fig. 1A). In contrast, in mice receiving pituitary isografts, although their estrous cycles lasted 5-6 days during a young period (40-70 days), the cycles became quite irregular in duration after 100 days of age (Fig. 1B and C).

In both strains, the pituitary weight in the mice receiving pituitary isografts (Groups 1, 3 and 5) was significantly smaller than that in the control mice (Groups 2 and 4). However, no significant difference in pituitary weight occurred in 35-day-old mice (Groups 6 and 7) (Table 3). In the ddY mice ovariectomized on the day of birth, the pituitary weight in the animals given pituitary grafts (Group 8) was also smaller than that in the controls (Group 9). No definite correlation was observed between the type of estrous cycles and the difference in pituitary weight.

Growing follicles as well as large corpora lutea were encountered in the ovaries of both kinds of mice, given pituitary grafts and control, excepting those of 35-day-old mice (Groups 6 and 7) which had no corpora lutea. However, the ovarian weight in 5-month-old $\mathrm{C} 3 \mathrm{H}$ mice given pituitary isografts (Group 1) was significantly larger than that in the control animals (Group 2) (Table 3). In the number of corpora lutea measuring more than $0.5 \mathrm{~mm}$ in diameter, the ovaries contained a larger number of them in the experimental group $(8.5 \pm 0.5)$ than in the control group $(3.6 \pm$ $0.8)(\mathrm{P}<0.001)$.

The mammary glands of the mice which had received pituitary isografts on neonatal days were different in structure according to the type of the estrous cycles. In animals exhibit-

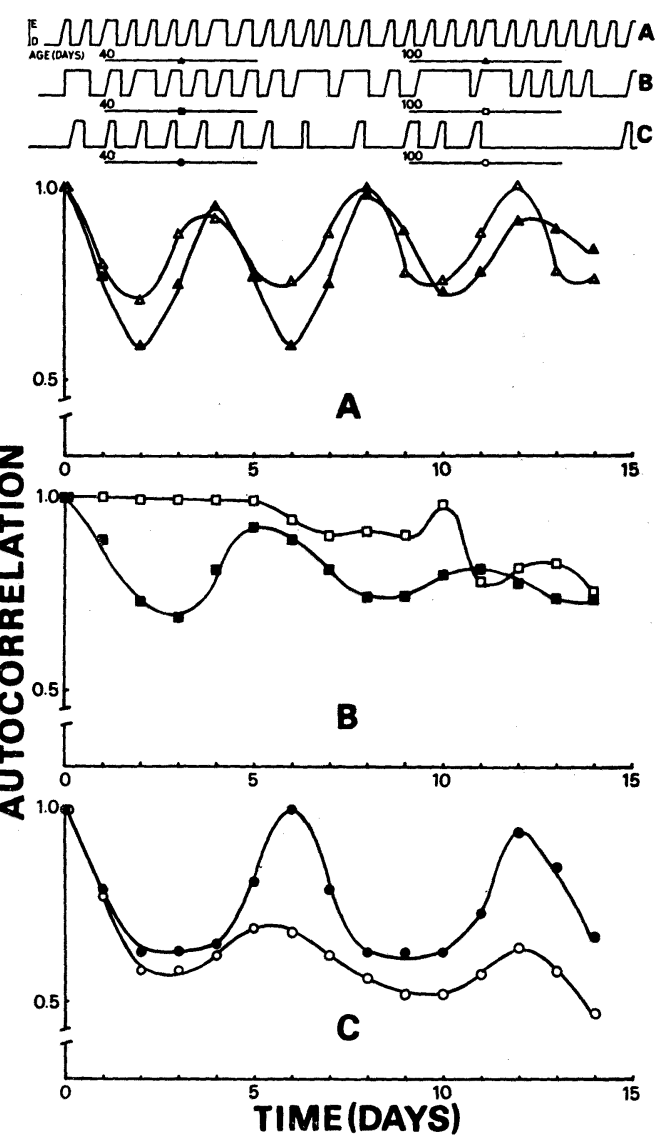

Fig. 1. Upper 3 graphs show vaginal cycles from the day of vaginal opening until sacrifice in a mouse receiving a submaxillary isograft and two mice given pituitary isografts. An oblique side of each peak in these graphs shows a proestrous phase. $\mathrm{E}$ : estrous, D: diestrous.

Lower 3 graphs show autocorrelation functions for a 30-day periods (underlined in the upper figures; see "Methods" for details). (A) Regular 4-day vaginal cycles in a control mouse. (B) Vaginal cycles with prolonged estrous in a mouse given a pituitary isograft. (C) Vaginal cycles with prolonged diestrous in a mouse given a pituitary isograft.

ing prolonged diestrus, the mammary glands had well-developed branching ducts with many scattering or small clustering alveoli, while in those showing prolonged estrous or regular cycles, the mammary glands were approximately the same in structure as those in the 
Table 3. Organ weights ( $\mathrm{mg} / 20 \mathrm{~g}$ body weight) in mice given neonatal pituitary isografts

\begin{tabular}{ccccc}
\hline Group & $\begin{array}{c}\text { Body } \\
\text { weight(g) }\end{array}$ & $\begin{array}{c}\text { Pituitary } \\
\text { weight } \\
(\mathrm{mg} / 20 \mathrm{~g} \mathrm{bd} \text { wt. })\end{array}$ & $\begin{array}{c}\text { Ovarian } \\
\text { weight } \\
(\mathrm{mg} / 20 \mathrm{~g} \text { bd wt. })\end{array}$ & $\begin{array}{c}\text { Adrenal } \\
\text { weight } \\
(\mathrm{mg} / 20 \mathrm{~g} \text { bd wt. })\end{array}$ \\
\hline 1 & $26.9 \pm 1.3$ & $1.16 \pm 0.05^{\mathrm{c}}$ & $12.5 \pm 0.6^{\mathrm{d}}$ & $5.2 \pm 0.2$ \\
2 & $25.9 \pm 0.9$ & $1.44 \pm 0.03^{\mathrm{c}}$ & $8.2 \pm 0.6^{\mathrm{d}}$ & $5.8 \pm 0.2$ \\
3 & $29.6 \pm 1.5$ & $1.79 \pm 0.07^{\mathrm{ef}}$ & $10.6 \pm 0.5$ & $7.2 \pm 0.3$ \\
4 & $27.9 \pm 1.6$ & $2.07 \pm 0.07^{\mathrm{egh}}$ & $10.1 \pm 0.7$ & $6.8 \pm 0.3^{\mathrm{i}}$ \\
5 & $31.8 \pm 1.1$ & $1.81 \pm 0.05^{\mathrm{g}}$ & $10.9 \pm 0.4$ & $6.3 \pm 0.2$ \\
6 & $22.2 \pm 0.5$ & $1.60 \pm 0.07$ & $8.3 \pm 0.8$ & $6.8 \pm 0.3$ \\
7 & $21.5 \pm 0.5$ & $1.73 \pm 0.10$ & $7.7 \pm 0.8$ & $6.2 \pm 0.3$ \\
8 & $31.3 \pm 0.8$ & $1.14 \pm 0.07^{\mathrm{fj}}$ & - & $4.5 \pm 0.3^{\mathrm{i}}$ \\
9 & $29.6 \pm 1.5$ & $1.49 \pm 0.09^{\mathrm{hj}}$ & - & $5.5 \pm 0.4$ \\
\hline
\end{tabular}

Notes: See Table 2.

control mice, bearing poorly branching ducts with terminal buds of different sizes. In the mammary glands of ovariectomized mice, branching ducts were thinner than in those of the other groups of mice with intact ovaries.

Histologic examination of the adrenals revealed no consistent differences between two kinds of mice, given pituitary grafts and control.

\section{Discussion}

The estrous cycles of the adult female mice which had received anterior pituitary isografts on neonatal days were often irregular, the duration of estrous or diestrous being sometimes prolonged. The pituitaries were smaller in weight in these animals than in the controls given submaxillary isografts.

In the present results, a retardation of the growth of the pituitary in situ in 3-month-old mice was observed even if the neonatal pituitary implantation was performed at 6 days of age. However, when the mice were killed at 1 month of age, no reduction in pituitary weight occurred. The growth of the pituitary in situ was also retarded even if the mice had been ovariectomized before neonatal pituitary implantation. Accordingly, some substance(s) released from the pituitary isografts appear(s) to have directly affected the pituitary of the mice.

It has been well established that an ectopic transplantation of the anterior pituitary results in a marked reduction in secretion of FSH, LH, STH, ACTH and TSH and in a pronounced increase in secretion of prolactin (Jacobsohn, 1966). Neonatal prolactin injections induce prolonged estrous in both mice and rats (Mori and Bern, 1972a; Nagasawa et al., 1973). According to Clemens et al. (1969) and Voogt et al. (1969), prolactin administration to immature rats causes an enhanced release of FSH which in turn stimulates secretion of estrogen from the ovaries. On the basis of these findings, an increased secretion of estrogen from the ovaries during early postnatal life seems responsible for the irregular estrous cycles found in the present results regarding adult mice given pituitary isografts on neonatal days.

In the 5-month-old mice receiving pituitary isografts, number of corpora lutea in their ovaries was larger than that in control animals. As mentioned elsewhere (Mori and Matsumoto, 1974), the stronger stimulation of the ovaries in the animals given pituitary isografts may be due to a possible increased secretion of pituitary gonadotropic hormones, since Nagasawa et al. (1973) recently reported that, in adult rats treated with prolactin on neonatal days, though both serum and pituitary levels of prolactin and serum levels of $\mathrm{LH}$ and FSH 
were almost the same as were those in the control rats at early proestrous, these levels were significantly high as compared with those in the controls on the 2 nd day of diestrous.

In some mice given pituitary isografts on neonatal days, the mammary glands exhibited an indication of being subjected to a hormonic stimulation. This finding is in harmony with a report that, in mice of $\mathrm{Balb} / \mathrm{cCrgl}$, a neonatal pituitary implantation was followed by an increased incidence of mammary tumor (unpublished data).

\section{Acknowledgement}

The author wishes to thank Professor K. Ueda for his valuable suggestions during the course of the experiment. $\mathrm{He}$ is also indebted to Professor Emeritus $\mathrm{K}$. Takewaki for his kind criticism and help in preparing the manuscript. This experiment was supported by Grant from the Japan Society for the Promotion of Science.

\section{References}

Blackman, R. B. and J. W. Tukey (1958). The mesurement of power spectra. Dover Publication Inc. New York.
Clemens, J. A., H. Minaguchi, R. Storey, J. L. Voogt and J. Meites (1969). Neuroendocrinol. 4, 150.

Isobe, T. (1968). Correlation and spectrum. Tokyo Daigaku Shuppan. Tokyo (In Japanese) (The title of the book is Soukan kansu oyobi supekutoru).

Jacobsohn, D. The technique and effect of hypophysectomy, pituitary stalk section and pituitary transplantation in experimental animals. "The pituitary gland" Vol. 2 (edited by G. W. Harris and B. T. Donovan) p. 1 (1966).

Mori, T. and H. A. Bern (1972a). U.S.-Japan seminar on longterm effects of perinatal hormone administration. Tokyo, p. 35.

Mori, T. and H. A. Bern (1972b). Proc. Japan Acad. 48, 698.

Mori, T. and A. Matsumoto (1974). Zool. Mag. 83, 110.

Nagasawa, H., R. Yanai, S. Kikuyama and J. Mori (1973). J. Endocrinol. 59, 377.

Voogt, J. L., J. A. Clemens and J. Meites (1969). Neuroendocrinol. 4, 157. 